\title{
NURSING ERRORS: A STUDY OF THE CURRENT LITERATURE ${ }^{1}$
}

\author{
Elaine Cristina Novatzki Forte², Denise Elvira Pires de Pires ${ }^{3}$, Maria Itayra Padilha, \\ Maria Manuela Ferreira Pereira da Silva Martins ${ }^{5}$
}

${ }^{1}$ Financially supported by the Coordenação de Aperfeiçoamento de Pessoal de Nível Superior (Capes).

${ }^{2}$ Doctoral student, Programa de Pós-Graduação em Enfermagem, Universidade Federal de Santa Catarina (UFSC). Capes Scholarship student. Florianópolis, Santa Catarina, Brazil. E-mail: elainecnforte@gmail.com

${ }^{3}$ Ph.D. in Nursing. Professor, Programa de Pós-Graduação em Enfermagem (PEN), UFSC. CNPq Reseacher. Florianópolis, Santa Catarina, Brazil. E-mail: piresdp@yahoo.com

${ }^{4}$ Ph.D. in Nursing. Professor, PEN/UFSC. CNPq Reseacher. Florianópolis, Santa Catarina, Brazil. E-mail: itayra.padilha@ufsc.br

${ }^{5}$ Ph.D. in Nursing. Professor, Coordenator in the Escola Superior de Enfermagem do Porto. Porto, Portugal. E-mail: mmartins@esenf.pt

\begin{abstract}
Objective: to characterize what the current literature states about nursing errors, with a specific review on how these errors are communicated to society by the media.

Method: a qualitative documental research, characterized as an integrative literature review, performed using four databases and guided by a formal protocol, in the period from 2011 to 2015, by two independent collaborators. The analysis of the studies occurred through the analysis of thematic content articulated with the resources of the Atlas.ti software.

Results: 32 studies were analyzed and organized into two macro categories: main errors practiced by the nursing team; reported forms of prevention to avoid errors. Such categories reveal that most of the errors are made with medication, the main causes are related to work overload and management problems, and the main sources of prevention are to improve working conditions, continuing education and safety culture.
\end{abstract}

Conclusion: nursing errors are determined by multiple factors and their coping requires professional and institutional measures.

DESCRIPTORS: Nursing team. Medication errors. Patient safety. Media. News.

\section{ERROS DE ENFERMAGEM: O QUE ESTÁ EM ESTUDO ${ }^{1}$}

\section{RESUMO}

Objetivo: caracterizar o que a literatura atual versa a respeito dos erros de enfermagem, em especial de como esses erros são comunicados à sociedade pela imprensa.

Método: pesquisa qualitativa, documental, caracterizada como revisão integrativa de literatura, realizada em quatro bases de dados e orientada por um protocolo formal, no período de 2011 a 2015, por duas colaboradoras independentes. A análise dos estudos encontrados se deu por meio da análise de conteúdo temática articulada com os recursos do software Atlas.ti.

Resultados: foram analisados 32 estudos e organizados em duas macrocategorias: principais erros praticados pela equipe de enfermagem; e causas relatadas e formas de prevenção para evitar os erros. Tais categorias revelam que a maioria dos erros é de medicação, as principais causas estão relacionadas à sobrecarga de trabalho e a problemas do âmbito da gestão, e as principais fontes de prevenção são a melhoria das condições de trabalho, a educação continuada e a cultura de segurança.

Conclusão: os erros de enfermagem são multideterminados e seu enfrentamento requer medidas no âmbito profissional e institucional. DESCRITORES: Equipe de enfermagem. Erro de medicação. Segurança do paciente. Meios de comunicação. Notícias. 


\section{ERRORES DE ENFERMERÍA: QUÉ ESTÁ EN ESTUDIO}

Objetivo: caracterizar lo que la literatura actual versa sobre los errores de enfermería, en especial de cómo estos errores son comunicados a la sociedad por la prensa.

Método: investigación cualitativa, documental, caracterizada como revisión integrativa de literatura, realizada en cuatro bases de datos y orientada por un protocolo formal, en el período de 2011 a 2015, por dos colaboradoras independientes. El análisis de los estudios encontrados se dio por medio del análisis de contenido temático articulado con los recursos del software Atlas.ti.

Resultados: se analizaron 32 estudios y organizados en dos macrocategorías: principales errores cometidos por el equipo de enfermería; $Y$ las causas relatadas y formas de prevención para evitar los errores. Estas categorías revelan que la mayoría de los errores son de medicación, las principales causas están relacionadas con la sobrecarga de trabajo y los problemas del ámbito de la gestión, y las principales fuentes de prevención son la mejora de las condiciones de trabajo, la educación continuada y la cultura de Seguridad.

Conclusión: los errores de enfermería son multideterminados y su enfrentamiento requiere medidas en el ámbito profesional e institucional. DESCRIPTORES: Grupo de enfermería. Errores de medicación. Seguridad del paciente. Medios de comunicación. Notícias.

\section{INTRODUCTION}

The issue of health care quality and patient safety has assumed significant relevance in recent years. In this context, nursing has been prominent in hospital accreditation processes and in programs aimed at improving the quality of health services. ${ }^{1-3}$

Although patient safety and quality health care quality are at the center of current discussions, errors in health care are being communicated to society as they are increasingly reported in the newspapers, television, and on the internet. This is explained by the outcome of the incident (deaths and / or severe sequelae) which cause many repercussions. In addition, when litigation is involved, the repercussion is much greater, especially because of the way they are reported and because of the consequences, such as length of hospital stay extended beyond what is necessary, complications in the general patient's condition, and even death of the patient. ${ }^{4}$

Nursing errors can be defined as an episode that resulted in unnecessary harm to the patient. Incidents during care, when the patient is not harmed or the errors are detected early, are called near miss incidents; when these incidents happen with the patient without causing harm, they are called incidents without harm; and when there is harm done to the patient, it is called the adverse event. ${ }^{5}$

Nursing errors are derived from adverse events (incidents that cause some harm to the patient) and iatrogenic errors (situations occurring as a result of treatment performed by these professionals) which occur during care and may be caused by incorrectly performed procedures, problems in prescribing care, inadequate management of the drug preparation process, and inadequate, damaged, or inadequate equipment. ${ }^{6}$ The errors, injuries, and adverse events associated with nursing professional care are diverse and should be at the top of the profession's concerns, as well as the health services and public policies.

In a study titled Estudo Ibero-Americano de Eventos Adversos (Ibero-American Study of Adverse Events) conducted between 2007 and 2009 in 58 hospitals in Latin America, 11,379 inpatients were observed. Among them, 1,191 patients had at least one adverse event related to care and, from this total, incapacity was caused in more than $28 \%$ of the patients and another $6 \%$ were associated with the death of the patient. The causes identified by the Latin American study were related to hospital infections $(37.13 \%)$, therapeutic and diagnostic procedures $(28.5 \%)$, general care $(13.4 \%)$, administration of medications $(8.32 \%)$ and diagnosis $(6.15 \%)$, with $6.5 \%$ of the events not being specified. ${ }^{7}$ These numbers are alarming and deserve attention in order to reduce the possibilities of these adverse events.

Among the adverse events resulting from nursing care, medication errors have been highlighted in the literature and in patient safety manuals. ${ }^{6}$ These are defined as any preventable events that may cause or induce the inappropriate use of medications, and these events may be related to a number of factors. ${ }^{8}$ According to the Food and Drug Administration, medication errors cause, on average, one death per day in the United States, which makes this problem even more frightening. ${ }^{9}$

Nursing is the health profession which works in the hospital 24-hour hours a day by the patient's bedside, and all the activities nurses perform require special care in order to maintain quality care and prevent errors during care. The mistakes made by nursing professionals have great repercussion especially when they are treated in a wrong way by the media. Thus, the present study aims to identify and characterize what is available in the current literature regarding errors involving the nursing team, in particular to literature which deals with how these errors are communicated to society by the media. 


\section{METHOD}

A bibliographical study conducted by two independent collaborators, using the assumptions of integrative literature review based on a protocol where all followed steps are identified. ${ }^{10-11}$ The inconsistencies found were analyzed by an external collaborator.

The search took place in July 2015 and was carried out in the databases: Banco de Teses e Dissertações da Coordenação de Aperfeiçoamento de Pessoal de Nível Superior (Capes); Virtual Health Library (BVS Enfermagem); Scientific Electronic Library Online - (SciELO); and the US National Library of Medicine National Institutes of Health (PubMed) of the National Center for Biotechnology Information (NCBI). The choice of databases was based on the following criteria: open access bases (to increase the possibility of online access of complete texts); and databases which were more appropriate to capture the publications made in Brazil and international literature dealing with the phenomenon in nursing.

The descriptors used were: Nursing, Nursing team, Medication errors, Patient Safety, Media and News. In order to meet the proposed goal of associating "nursing error and way in which it was communicated to the press the following Boolean operators were used descriptors articulated by Boolean operators:

Enfermagem/Nursing OR Equipe de enfermagem/Nursing team AND Erros de medicação/ Medication erros AND Meios de comunicação/communications media OR Notícias/News.

Enfermagem/Nursing OR Equipe de enfermagem/Nursing team AND Gerenciamento de riscos/ Risk management AND Meios de comunicação/communications media OR Notícias/News.

Enfermagem/Nursing OR Equipe de enfermagem/Nursing team AND Segurança do paciente/ Patient safety AND Meios de comunicação/communications media OR Notícias/News.

Studies published in the format of complete scientific articles, theses and dissertations, containing the key words listed in the protocol in the abstract and / or title, published in English and Portuguese, from 2011 to 2015, and whose general objective and / or specific reference was made explicitly to the object of study, were included.

The following were defined as exclusion criteria: publications in the form of letters, reviews and editorials, integrative and systematized reviews, books, book chapters, government documents and newsletters, as well as studies that are not available on-line in full for analysis, and publications outside of the period of interest or duplicated publications. In a first search, there were 254 studies which when the inclusion and exclusion criteria were applied, 96 were excluded because they did not meet the objective of this study; 72 were duplicated studies and 54 were not available in full by online access.

The selected studies were organized into a qualitative data analysis software, Atlas.ti 7.0, articulating the resources of the software with the precepts of thematic analysis, respecting the steps of pre-analysis, material exploration, and treatment and interpretation of the results. ${ }^{12}$ All ethical care was taken in the analysis of the documents, respecting the ideas of the authors and the analyzed content.

Each study included in the review was inserted as a primary document (Atlas.ti language) in a hermeneutical unit created in the software. During the exhaustive reading of the studies the registration units (quotations) were selected and according to the core meaning each one received distinct code (coding process). The combination of similar codes formed large categories of meanings (families), which are arranged in the figures (networks) generated by the software itself. The organization and analysis of the data gave rise to two macro categories: The main errors practiced by the nursing team and reported causes; and ways to avoid errors.

\section{RESULTS}

The corpus of the research was composed of 32 studies, which were analyzed based on codes assigned to the quotations, selected from the documents inserted in the Atlas.ti software. Afterwards, the profile of the studies was described and the main findings were organized into two macro categories.

\section{Profile of the studies}

The studies that were part of this review are presented in Table 1. At a later stage, the main findings was described regarding the nature of the study, language, country of publication, method of data collection, incidence of errors and the main drugs involved with medication errors. 
Table 1 - Presentation of publications on nursing errors, second year of publication, type, periodical and authors. Florianópolis-SC, 2015

\begin{tabular}{|c|c|c|c|}
\hline Year & Type & Periodical & Author (s) \\
\hline 2012 & Thesis & - & Teixeira TCA. ${ }^{13}$ \\
\hline 2015 & Article & Rev Enferm UFPE & Fontana RT, et al. ${ }^{14}$ \\
\hline 2011 & Article & Rev Bras Enferm & Belela ASC, Pedreira MLG, Peterlini MAS. ${ }^{15}$ \\
\hline 2011 & Article & Rev Bras Enferm & Corbellini VL, et al. ${ }^{16}$ \\
\hline 2015 & Article & Acta Paul Enferm & Yamamoto MS, Peterlini MAS, Bohomol E. ${ }^{17}$ \\
\hline 2014 & Article & Rev Esc Enferm USP & Paranaguá TTB, et al. ${ }^{18}$ \\
\hline 2013 & Article & Rev Latino-am Enfermagem & Silva AEBC, Cassiani SHB..$^{19}$ \\
\hline 2013 & Article & Enferm Foco & Lopes BC, et al. ${ }^{20}$ \\
\hline 2011 & Article & Rev Min Enferm & Praxedes MFS, Telles Filho PCP..$^{21}$ \\
\hline 2013 & Article & J Res Pharm Pract & Shahrokhi A, Ebrahimpour F, Ghodousi A.22 \\
\hline 2013 & Article & Intensive Care Med & Valentin A, et al. ${ }^{23}$ \\
\hline 2011 & Article & Nurs Res & Chang Y, Mark B. ${ }^{24}$ \\
\hline 2013 & Article & Worldviews Evid Based Nurs & Hartnell N, et al. ${ }^{25}$ \\
\hline 2012 & Article & Am J Nurs & West G, Patrician APA, Loan L. ${ }^{26}$ \\
\hline 2012 & Article & Critical Care Nurs & Mattox EA..$^{27}$ \\
\hline 2014 & Article & Rev Enferm Esc Anna Nery & Bohomol E. ${ }^{28}$ \\
\hline 2011 & Article & Rev Gaúcha Enferm & Veloso IR, Telles Filho PCP, Durão AMS. ${ }^{29}$ \\
\hline 2011 & Article & Texto Contexto Enferm & Camerini FG, Silva LD..$^{30}$ \\
\hline 2012 & Article & Texto Contexto Enferm & Silva LD, Camerini FG. ${ }^{31}$ \\
\hline 2011 & Article & Rev Latino-am Enfermagem & Silva AEBC, et al. ${ }^{32}$ \\
\hline 2014 & Article & Rev Pesqui Cuid Fundam & Ferreira PC, et al. ${ }^{33}$ \\
\hline 2012 & Article & Health Service Res & Lawton R, et al. ${ }^{34}$ \\
\hline 2015 & Article & Crit Care Med & Marquet K, et al. ${ }^{35}$ \\
\hline 2012 & Article & Rev Enferm Esc Anna Nery & Roque KE, Melo ECP. ${ }^{36}$ \\
\hline 2014 & Article & Rev Gaúcha Enferm & Lorenzini E, Santi JAR. Báo ACP. ${ }^{37}$ \\
\hline 2014 & Article & Acta Paul Enferm & Teixeira TCA, Cassiani SHB. ${ }^{38}$ \\
\hline 2013 & Article & Rev Saúde Pública & Rozenfeld S, Giordani F, Coelho S. ${ }^{39}$ \\
\hline 2012 & Dissertation & - & Dalmolin GR..$^{40}$ \\
\hline 2012 & Article & Acta Paul Enferm & Harada MJCS, et al. ${ }^{41}$ \\
\hline 2012 & Article & Rev Min Enfermagem & Lemos NRF, Silva VR, Martinez MR.42 \\
\hline 2014 & Article & Cad Saúde Coletiva & Pichler RF, et al. ${ }^{43}$ \\
\hline 2012 & Article & Rev Assoc Med Bras & Lopes DMA, et al..$^{44}$ \\
\hline
\end{tabular}

Regarding the nature of the studies, 21 are quantitative, seven qualitative and four theoretical essays. The predominant language was Portuguese, with 23 studies and 9 publications in English. The country with the highest number of publications was Brazil with 22 studies, followed by the United States with nine and New Zealand with one study.
Most of the studies used documentary research to collect data (14 studies) in medical records, and reports; nine studies used non-participant observation, ten studies used interviews or questionnaires, two used photographic analysis and one used case study. The incidence in studies which observed drug administration and those who evaluated the reporting of errors ranged from $14.3 \%$ to $56 \%$. 
The most common types of medication with errors were intravenous anesthetics (43.3\%), followed by antineoplastic and immunomodulators $(24.3 \%)$, antibiotics and analgesics $(25.2 \%)$ and gastric acidity reducers (19\%).
Main errors made by the nursing team and related causes

The types of errors described in the studies and the reported causes are presented in Figures 1 and 2.

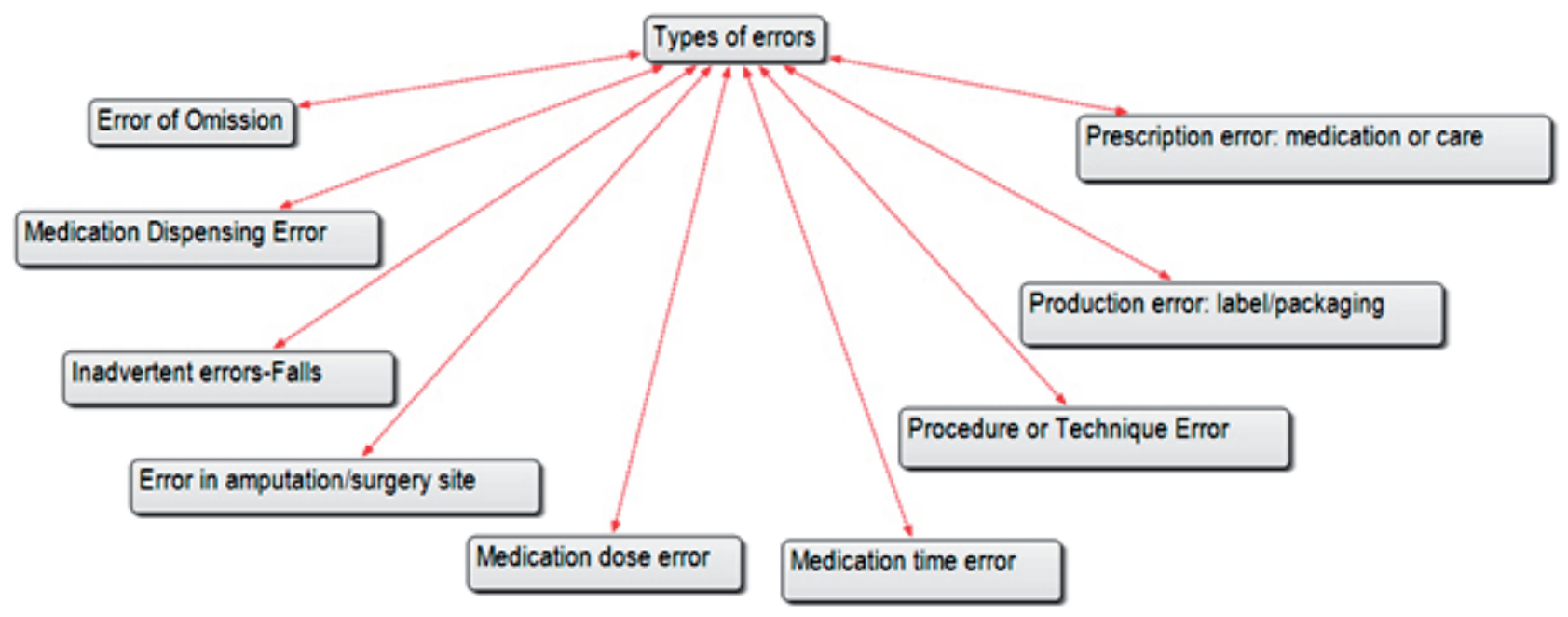

Figure 1 - Types of errors, Florianópolis-SC, 2015

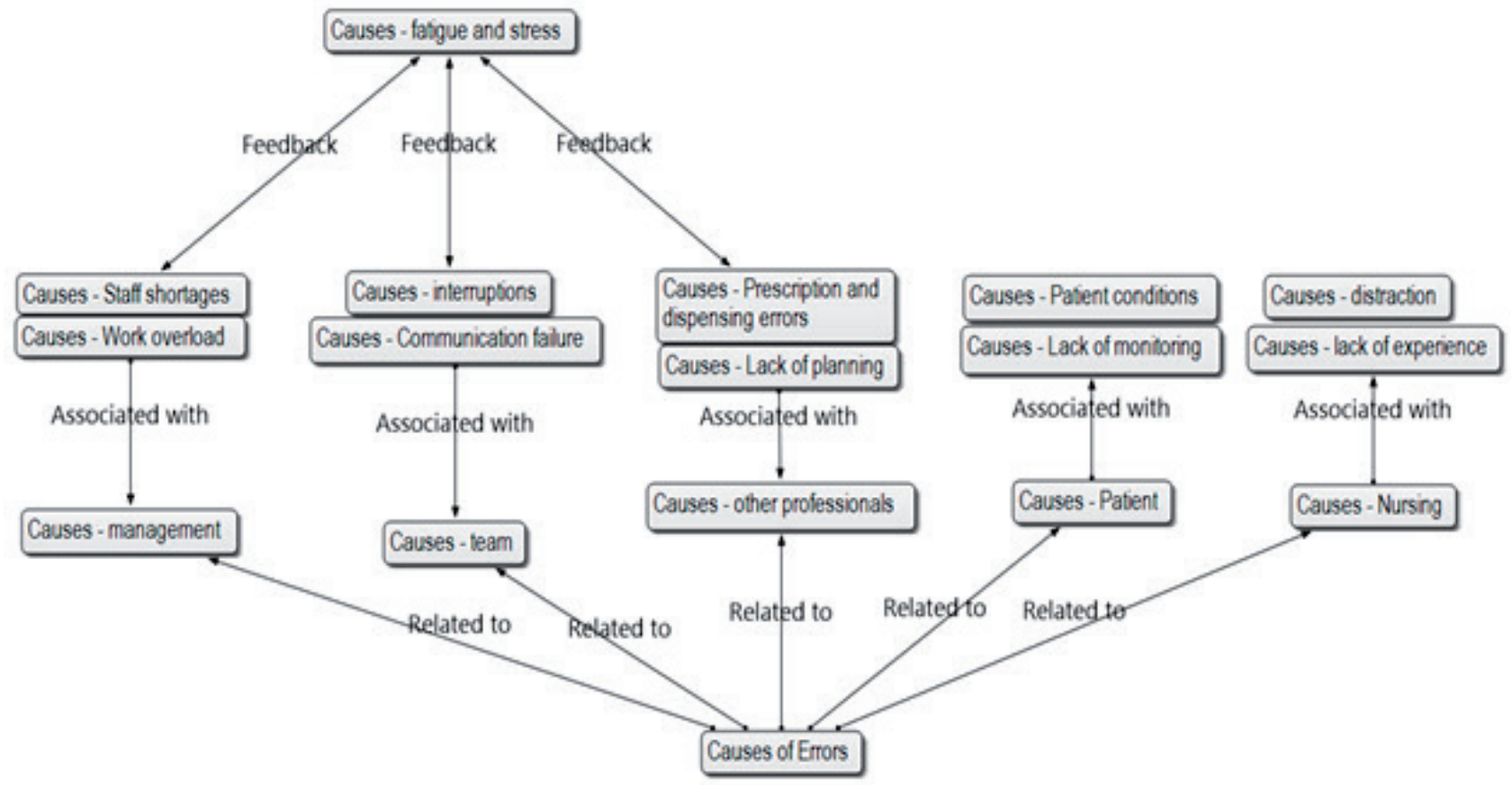

Figure 2 - Causes of errors, Florianópolis-SC, 2015

\section{Prevention and methods to avoid errors}

All the studies analyzed present contributions related to the prevention of errors, one of them had these contributions as the objective, the others suggest means to reduce or avoid errors.
Among the various ways to avoid errors, the following were highlighted:

- Improvements in the nursing work process, understanding it as complex, hampered by working conditions, especially due to the high 
demand for care, work overload and insufficient remuneration; ${ }^{13-27}$

- Continuing education at work as an effective method to prevent adverse events; ${ }^{13-14,16-17,19-21,24,28-35}$

- Importance of notifying adverse events in order to understand them and to devise strategies to avoid them; $28,34,36-39$

- Development of a patient safety culture by professionals; ${ }^{23-24,37-38}$

- Institutions should avoid punitive attitudes, stimulating an educative culture for their professionals. ${ }^{16,19-21,38}$

\section{DISCUSSION}

Among all the studies analyzed, the greatest emphasis was given to medication errors, ${ }^{13-20,22-23,29-35,37-38,40,42-43}$ this is due to the choice of studies that recommended analyzing the errors done by the nursing team, who are mainly responsible for this activity. Falls were reported in four studies, but with less incidences. ${ }^{13,30,38-39}$ The rate of medication infusion ${ }^{17,19,42}$ and time errors (anticipating or delaying the preparation or administration of the drug) have greater prominence in the literature, especially, for the outcome of this type of error, which ranges from the failure in the patient's therapy to the possible death of a patient.

The physical structure was analyzed from the point of view of ergonomics. ${ }^{44}$ It was found that structural issues, such as medication storage, transportation of medication by trays and the identification of materials can be considered error inducers if they are not well organized.

In 2013, the Centro Colaborador para Qualidade do Cuidado e Segurança do Paciente (Proqualis Collaborating Center for Quality of Care and Patient Safety) translated and subtitled a video conducted by the World Health Organization regarding the administration error of the drug Vincristina. The video shows how an adverse event related to medication can be triggered by describing a sequence of events within a hospital that culminates in a serious error in the administration of the chemotherapeutic drug Vincristine. It is important to highlight that when we are faced with a medication error, we must evaluate the whole process involved in this practice, in which the result may be only the tip of the iceberg, in the sense that the greater base remain submerged, or rather, the issues that determine the errors are not properly exposed or analyzed.
The empirical evidence shows that health professionals are prone to make mistakes in the preparation and administration of medications, however, these errors are strongly induced by working conditions in health institutions. ${ }^{45}$

The highest frequency of errors was detected in the Hospitalization Units, $13,18-19,26-27,30,32,37,43$ in the Intensive Care Units (ICU) ${ }^{20,23,28,30,42}$ and in pediatrics. ${ }^{15,17,29,41}$ This can be explained by several factors related to the characteristics of users and the specificities of these units.

In the ICU, as the denomination itself suggests, patients are in a critical state of health and require increased levels of care, and the quantity and variety of medications and procedures used are great. In the hospitalization units, the picture is often not very different from the ICU, because the health situation is also critical and the number of hospitalized patients is much higher. Inpatient units are considered to be areas of major concern for patient safety, and the care provided directly interferes with the results of hospital-based health care. ${ }^{46}$

As for the children, they present greater vulnerability due to many factors, among them includes their anatomical and physiological condition itself, with emphasis on the use of off label (when the medication is used without its approved use for that age group, or rather, when the indication for that specific clientele is not yet included in the medication label), since the pharmaceutical industry is not yet focused on serving this specific public.

Medication errors, as well as adverse drug reactions in the pediatric clientele, are closely related to drug interaction and the absence of drugs directed exclusively to the needs of children. ${ }^{47}$

Other adverse events resulting from nursing care, such as falls and injuries, were less discussed. However, falls are one of the main adverse events which occur during nursing care, ${ }^{48}$ and falls prevention is one of the six goals of patient safety established by the WHO.

The causes of errors reported in the studies are diverse and attributed to the entire health care system. Thus, the category of organizational processes management had the greatest prominence, $13,17-19,22,26,34-35,38,40$ because management can contribute to the appearance of other causes, such as: deficiencies in the physical infrastructure, ${ }_{1}^{13,17,19,21,29,37,44}$ shortages in the

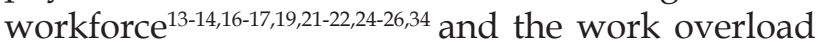
of the professionals. ${ }^{13-14,16,19.21-23.25-26,34,37-38,44}$

In the study that analyzed medicine labeling, ${ }^{44}$ there was a surprising result which showed that $43 \%$ 
of medicines were considered "possibly similar", $44 \%$ had the "same color label or packaging" and the "same word order", being that $50.7 \%$ of the medicines were identified as having "same color of the words". The results have identified that these labeling similarities can greatly contribute to errors in storage, dispensing and administering of medications.

The staff shortages as well as work overload seem to be strongly linked to incidents involving nursing errors, and both are related to health service management decisions. ${ }^{45,49}$ This problem does not only affect the patient's safety, but also the safety of the professionals themselves, and are seem as important predictors of dissatisfaction and demotivation at work. Therefore, in the great majority of the studies found, the improvement of the working conditions is a determinant factor to patient safe. Sufficient professionals with a fair workload and adequate structure can guarantee quality care without adding harmful effects to patients' health.

The human factor, i.e., the nursing professionals themselves, also carry the burden of the causes of errors, and the most frequent causes attributed to the individual staff and professional are: distraction, $16,19,21-22,27,38,42,44$ communication failures $13-14,17,24-32,34-35$ and lack of knowledge. ${ }^{14,17-19,21,29-30,32,34,38,44}$ Distractions and communication failures are reported in other studies as factors that may predispose the occurrence of errors during care, since distractions take the professional from the focus, which at that moment is the patient, and efficient communication between the team can minimize and even prevent errors. ${ }^{45.50}$

The other professionals are attributed to the causes of errors of prescription and dispensation, ${ }^{16,21,38,40,43-44}$ being that they become the start for the sequence of processes that will culminate in the error.

The only study that analyzed the nursing errors portrayed in the media ${ }^{14}$ offers an important contribution to the theme. When analyzing the adverse events in nursing practice portrayed in the newspapers between 2007 and 2012, it was found that the errors related to medication administration were prominent, corroborating with the previous findings of this review. In the study in question, there were 29 news reports about the subject, which were defined by the authors as records without explicit, though controversial, judgment. Nursing professionals such as nurse technicians were present in the vast majority of the reports. The study highlights the importance of clarifying the conditions of nursing training and the work of the nurse to society, understood as conditions for error, and the value given to discussions on this theme in order to strengthen initiatives to improve the quality of care in nursing and health.

Similarly, other studies also stress the importance of reporting adverse events, which should be perceived by professionals as essential for the safety culture, since it values the goal of minimizing the damages caused and values learning. Institutions should therefore be aware that the merely punitive culture is not effective because management must strive to promote the education of its workers ${ }^{51}$ Thus, continuing education is an effective way for both prevention and for minimization and must be encouraged by institutions. ${ }^{51}$

Finally, developing a patient safety culture within health institutions is critical to ensure that quality care is expected in all health settings, "in which all workers, including caregivers and managers, take responsibility for their own safety, and for the safety of their colleagues, patients and family." 52:2

To err is human, however, no health professional wants or intends to err (with the exception of intentional cases, which is not the subject of this study), so the importance of understanding all incidents in order to reduce recurrence, done so through protocols, continuing education and structural changes become the barriers to further errors. ${ }^{6,53}$

Nursing errors are made up of tangles of possible failures that are not detected in time to prevent them, formulating a complex network of cause and effect. The improvement of nursing work conditions and the need for continuing education have stood out as factors capable of preventing errors from materializing.

The limitations of this study refer to: the choice of pre-established descriptors and the association with Boolean operators, established in the previous protocol, in particular the association with the descriptor that associated the nursing error and communication by the media, present in all the search keys; the limitation of the search to the English and Portuguese languages; and the issue of the unavailability of the full text of some studies. These limitations may have reduced the corpus of the research.

\section{CONCLUSION}

This review has shown that nursing errors have been studied in many ways, in the context of patient safety, risk management and, in particular, medication errors. Many types of errors are described and multiple causes are tied to these events. 
It is worth mentioning the fact that the studies aimed not only to identify these events in a superficial way, but to deepen the knowledge about their possible causes and prevention factors. The contributions, although diversified, guide nursing professionals to provide safe care with responsibility and ethics, and direct health institutions in adjusting working conditions and favor the education of their professionals, contributing to the quality of health care. This perspective allowed everybody to benefit: the institutions for providing a qualified service free of litigation, the professionals for being recognized for their competences and mainly, the users of the services, who will be adequately taken care of.

However, it should be noted that only one study dealt with how these errors are communicated by the media, which instigates further investigations on this phenomenon, since the media repeatedly draws attention to medical and nursing errors and plays an important role in the relationship of health services, professionals and society.

\section{REFERENCES}

1. Organização Pan-Americana da Saúde (OPAS). Enfermería y seguridad de los pacientes. Washington (US): OPAS; 2011.

2. Knodel LJ. Nurse to nurse: administração em enfermagem. Porto Alegre (RS): Artmed; 2011.

3. Denser CPAC. Indicadores: instrumento para a prática de enfermagem com qualidade. In: Bork AMT. Enfermagem de excelência: da visão à ação. Rio de Janeiro: Guanabara Koogan; 2011.

4. Roque KE, Melo ECP. Avaliação dos eventos adversos a medicamento. Esc Anna Nery Rev Enferm [Internet] 2012 Jan-Mar [cited 2016 Jul 15]; 16(1):121-7. Available from: http://dx.doi.org/10.1590/S141481452012000100016

5. World Health Organization. Patient safety research: introductory course - Session 1 . What is patient safety? [place unknown]: WHO; 2012 [cited 2014 jul. 15]. Available from: http://www.who.int/ patientsafety/ research/online_course/en/

6. Ministério da Saúde (BR). Agência Nacional de Vigilância Sanitária. Assistência segura: uma reflexão teórica aplicada à prática. Série Segurança do Paciente e Qualidade em Serviços de Saúde. Brasília (DF): Anvisa; 2013.

7. Aranaz-Andrés JM, Aibar-Remón C, Limón-Ramírez $\mathrm{R}$, Amarilla A, Restrepo FR, Urroz O, et al._Prevalence of adverse events in the hospitals of five Latin American countries: results of the "Iberoamerican study of adverse events" (IBEAS). BMJ Qual Saf [Internet]. 2011 Dec [cited 2016 Jul 15]; 20(12):104351. Available from: http://dx.doi.org/10.1136/ bmjqs.2011.051284

8. National Coordinating Council for Medication Error Reporting and Prevention [Internet]. United States: National Coordinating Council; c1998-2010 [cited 2014 jun 14]. Available from: http://www.nccmerp.org/ aboutMedErrors.html

9. United States, Food and Drug Administration. [Internet] [cited 2014 jul 14]. Available from: http: / / www.fda.gov / consumer/updates / medicationerrors031408.html

10. Whittemore R, Knafl K. The integrative review: updated methodology. J Adv Nurs [Internet]. 2005 [cited 2016 Jul 15]; 52(5):546-53. Available from: http:/ / dx.doi.org/10.1111/j.1365-2648.2005.03621.x

11. Polit DF, Beck CT. Nursing research: generating and assessing evidence for nursing practice. Lippincott (US): Williams \& Wilkins; 2012.

12. Bardin L. Análise de conteúdo. Lisboa (PT): Edições 70; 2011.

13. Teixeira TCA. Análise de causa raiz de incidentes relacionados à segurança do paciente na assistência de enfermagem em unidades de internação, de um hospital privado, no interior do Estado de São Paulo [tese]. Ribeirão Preto (SP): Universidade de São Paulo; 2012.

14. Fontana RT, Wolf J, Rodrigues FCP, Castro LM. Análise documental da mídia escrita sobre eventos adversos ocorridos na prática da enfermagem. Rev Enferm UFPE on line [Internet]. 2015 [cited 2016 Jul 15]; 9(4):8103-10. Available from: http://dx.doi. org/10.5205/reuol.6235-53495-1-RV.0904supl201516

15. Belela ASC, Pedreira MLG, Peterlini MAS. Erros de medicação em pediatria. Rev Bras Enferm [Internet]. 2011 [cited 2016 Jul 15]; 64(3):563-9. Available from: http:/ / dx.doi.org/10.1590/S0034-71672011000300022

16. Corbellini VL, Schilling MC, Frantz SF, Godinho TG, Urbanetto JS. Eventos adversos relacionados a medicamentos: percepção de técnicos auxiliares de enfermagem. Rev Bras Enferm [Internet]. 2011 [cited 2016 Jul 15]; 64(2): 241-7. Available from: http:/ / dx.doi.org/10.1590/S0034-71672011000200004

17. Yamamoto MS, Peterlini MAS, Bohomol E. Notificação espontânea de erros de medicação em hospital universitário pediátrico. Acta Paul Enferm [Internet]. 2015 [cited 2016 Jul 15]; 24(6):766-71. Available from: http:/ / dx.doi.org/10.1590/S0103-21002011000600006

18. Paranaguá TTB, Bezerra ALQ, Santos ALM, Silva AEBC. Prevalência e fatores associados aos incidentes relacionados à medicação em pacientes cirúrgicos. Rev Esc Enferm USP [Internet]. 2014 [cited 2016 Jul 15]; 48(1):41-8. Available from: http://dx.doi. org/10.1590/s0080-623420140000100005

19. Silva AEBC, Cassiani SHB. Análise prospectiva de risco do processo de administração de medicamentos antiinfecciosos. Rev Latino-am Enfermagem [Internet]. 2013 [cited 2016 Jul 15]; 21(Spec). Available from: http:/ / dx.doi.org/10.1590/S0104-11692013000700029 
20. Lopes BC, Vargas MAO, Azeredo NSG, Behenck A. Erros de medicação realizados pelo técnico de enfermagem na UTI: contextualização da problemática. Enferm Foco [Internet]. 2013 [cited 2016 Jul 15]; 3(1): 16-21. Available from: http://revista.portalcofen.gov.br/ index.php/enfermagem/article/view/214/135

21. Praxedes MFS, Telles Filho PCP. Erros e ações praticadas pela instituição hospitalar no preparo e administração de medicamentos. REME Rev Min Enferm [Internet]. 2011 [cited 2016 Jul 15]; 15(3):40611. Available from: http://www.dx.doi.org/s141527622011000300014

22. Shahrokhi A, Ebrahimpour F, Ghodousi A. Factors effective on medication errors: a nursing view. J Res Pharm Pract [Internet]. 2013 [cited 2016 Jul 15]; 2(1):1823. Available from: http://dx.doi.org/10.4103/2279042X.114084

23. Valentin A, Schiffinger M, Steyrer J, Huber C, Strunk G. Safety climate reduces medication and dislodgement errors in routine intensive care practice. Intensive Care Med [Internet]. 2013 [cited 2016 Jul 15]; 39: 391-8. Available from: http:/ / dx.doi.org/10.1007/ s00134-012-2764-0

24. Chang Y, Mark B. Moderating effects of learning climate on the impact of RN staffing on medication errors. Nurs Res [Internet]. 2011 [cited 2016 Jul 15]; 60(1):32-9. Available from: http://dx.doi. org/10.1097/NNR.0b013e3181ff73cc

25. Hartnell N, MacKinnon N, Sketris I, Fleming M. Identifying, understanding and overcoming barriers to medication error reporting in hospitals: a focus group study. Worldviews Evid Based Nurs [Internet]. 2013 [cited 2016 Jul 15]; 10(2):82-94. Available from: http:/ / dx.doi.org/10.1136/bmjqs-2011-000299

26. West G, Patrician APA, Loan L. Staffing matters every shift. Am J Nurs [Internet]. 2012 [cited 2016 Jul 15]; 112(12):22-7. Available from: http://dx.doi. org/10.1097/01.NAJ.0000423501.15523.51

27. Mattox EA. Strategies for improving patient safety: linking task type to error type. Crit Care Nurs [Internet]. 2012 [cited 2016 Jul 15]; 32(1):52-78. Available from: http:/ /dx.doi.org/10.4037/ccn2012303

28. Bohomol E. Erros de medicação: estudo descritivo das classes dos medicamentos e medicamentos de alta vigilância. Esc Anna Nery Rev Enferm [Internet]. 2014 [cited 2016 Jul 15]; 18(2):311-6. Available from: http:/ / dx.doi.org/10.5935/1414-8145.20140045

29. Veloso IR, Telles Filho PCP, Durão AMS. Identificação e análise de erros no preparo de medicamentos em uma unidade pediátrica hospitalar. Rev Gaúcha Enferm [Internet]. 2011 [cited 2016 Jul 15]; 2(1):93-9. Available from: http://dx.doi.org/10.1590/S198314472011000100012

30. Camerini FG, Silva LD. Segurança do paciente: análise do preparo de medicação intravenosa em hospital da rede sentinela. Texto Contexto Enferm [Internet]. 2011 [cited 2016 Jul 15]; 20(1):41-9. Available from: http:/ /
dx.doi.org/10.1590/S0104-07072011000100005

31. Silva LD, Camerini FG. Análise da administração de medicamentos intravenosos em hospital da rede sentinela. Texto Contexto Enferm [Internet]. 2012 [cited 2016 Jul 15]; 21(3): 633-41. Available from: http://dx.doi.org/10.1590/S0104-07072012000300019

32. Silva AEBC, Reis AMM, Miasso AI, Santos JO, Cassiani SHB. Eventos adversos a medicamentos em um hospital sentinela do Estado de Goiás, Brasil. Rev Latino-am Enferm [Internet]. 2011 [cited 2016 Jul 15]; 19(2):09 telas. Available from: http:/ / www.scielo.br/ pdf/rlae/v19n2/pt_21

33. Ferreira PC, Dantas ALM, Diniz KD, Ribeiro KRB, Machado RC, Tourinho FSV. Evento adverso versus erro de medicação: percepções da equipe de enfermagem atuante em terapia intensiva. Rev Pesqui Cuid Fundam (Online) [Internet]. 2014 [cited 2014 Jul 14]; 6(2):725-34.. Available from: http:/ / www.index-f. com/pesquisa/2014/r6-725.php

34. Lawton R, Carruthers S, Gardner P, Wright J, McEachan RR. Identifying the latent failures underpinning medication administration errors: an exploratory study. Health Serv Res [Internet]. 2012 [cited 2016 Jul 15]; 47(4):1437-59. Available from: http:/ / dx.doi.org/10.1111/j.1475-6773.2012.01390.x

35. Marquet K, Claes N, De Troy E, Kox G, Droogmans M, Schrooten $\mathrm{W}$, et al. One fourth of unplanned transfers to a higher level of care are associated with a highly preventable adverse event: a patient record review in six belgian hospitals. Crit Care Med [Internet]. 2015 [cited 2016 Jul 15]; 43(5): 1053-61. Available from: http:/ / dx.doi.org/10.1097/CCM.0000000000000932

36. Roque KE, Melo ECP. Avaliação dos eventos adversos a medicamento. Esc Anna Nery Rev Enferm [Internet]. 2012 [cited 2016 Jul 15]; 16(1): 121-7. Available from: http:/ /dx.doi.org/10.1590/S1414-81452012000100016

37. Lorenzini E, Santi JAR, Báo ACP. Segurança do paciente: análise dos incidentes notificados em um hospital do sul do Brasil. Rev Gaúcha Enferm [Internet]. 2014 [cited 2016 Jul 15]; 35(2):121-7. Available from: http://dx.doi.org/10.1590/19831447.2014.02.44370

38. Teixeira TCA, Cassiani SHB. Análise de causa raiz de acidentes por quedas e erros de medicação em hospital. Acta Paul Enferm [Internet]. 2014 [cited 2016 Jul 15]; 27(2):100-7. Available from: http://dx.doi. org/10.1590/1982-0194201400019

39. Rozenfeld S, Giordani F, Coelho S. Eventos adversos a medicamentos em hospital terciário: estudo piloto com rastreadores. Rev Saúde Pública [Internet]. 2013 [cited 2016 Jul 15]; 47(6):1102-11. Available from: http:/ / dx.doi.org/10.1590/S0034-8910.2013047004735

40. Dalmolin GRS. Erros de medicação no ambiente hospitalar: uma abordagem através da bioética complexa [dissertação]. Porto Alegre (RS): Universidade Federal do Rio Grande do Sul; 2012.

41. Harada MJCS, Chanes DC, Kusahara DM, Pedreira 
MLG. Segurança na administração de medicamentos em Pediatria. Acta Paul Enferm [Internet]. 2012 [cited 2016 Jul 15]; 25(4):639-42. Available from: http:// dx.doi.org/10.1590/S0103-21002012000400025

42. Lemos NRF, Silva VR, Martinez MR. Fatores que predispõem à distração da equipe de enfermagem durante o preparo e a administração de medicamentos. Rev Min Enferm [Internet]. 2012 [cited 2016 Jul 15]; 16(2):201-7. http:/ / www.dx.doi.org/S141527622012000200008

43. Pichler RF, Garcia LJ, Seitz EM, Merino GSAD, Gontijo LA, Merin EAD. Erros de medicação: análise ergonômica de utensílios da sala de medicação em ambiente hospitalar. Cad Saúde Coletiva [Internet]. 2014 [cited $2016 \mathrm{Jul}$ 15]; 22(4):365-71. Available from: http:/ / dx.doi.org/10.1590/1414-462×201400040004

44. Lopes DMA, Néri EDR, Madeira LS, Souza Neto PJ, Lélis ARA, Souza TR, et al. Análise da rotulagem de medicamentos semelhantes: potenciais erros de medicação. Rev Assoc Med Bras [Internet]. 2012 [cited 2016 Jul 15]; 58(1): 95-103. Available from: http:// www.scielo.br/pdf/ramb/v58n1/v58n1a21.pdf

45. Keers RN, Williams SD, Cooke J, Ashcroft DM. Causes of medication administration errors in hospitals: a systematic review of quantitative and qualitative evidence. Drug Saf [Internet]. 2013 [cited 2016 Jul 15]; 36(11):1045-67. Available from: http://dx.doi. org/10.1007/s40264-013-0090-2

46. Lorenzetti J. "PRAXIS": tecnologia de gestão de unidades de internação Hospitalares [tese]. Florianópolis (SC): Universidade Federal de Santa Catarina, Programa de Pós-Graduação em Enfermagem; 2013.

47. Martins TSS, Silvino ZR, Silva LR. Eventos adversos na terapia farmacológica pediátrica: revisão integrativa da literatura. Rev Bras Enferm. 2011 Jul-Ago [cited 2016 Jul 15]; 64(4):745-50. Available from: http:/ / dx.doi.org/10.1590/S0034-71672011000400018

48. Luzia MF, Almeida MA, Lucena AF. Mapeamento de cuidados de enfermagem para pacientes com risco de quedas na Nursing Interventions Classification. Rev Esc Enferm USP [online]. 2014 Ago [cited 2015 Jul. 2015]; 48 (4):632-40. Available from: http:// www.scielo.br/scielo.php?script=sci_arttext\&pi$\mathrm{d}=$ S008062342014000400632\&lng=en\&nrm=iso.

49. Vazin A, Delfani S. Medication errors in an internal intensive care unit of a large teaching hospital: a direct observation study. Acta Med Iran. 2012; [cited 2015 Jul. 2015]. 50(6):425-32. Avaliable from: http://acta. tums.ac.ir/index.php/acta/article/view/3924/3899

50. Smeulers M, Verweij L, Maaskant JM, Boer M, Krediet $\mathrm{CT}$, Nieveen van Dijkum EJ, et al. Quality indicators for safe medication preparation and administration: a systematic review. PLos ONE. 2015 Apr [cited 2016 Jul 15]; 10(4):e0122695. Available from: http:/ / dx.doi. org/10.1371/journal.pone.0122695.

51. Ferreira MMM, Alves FS, Jacobina FMB. O profissional de enfermagem e a administração segura de medicamentos. Rev Enferm Contemp. 2014 Jun [cited 2016 Jul 15]; 3(1):61-9. 2014. Available from: http:/ / dx.doi.org/10.17267/2317-3378rec.v3i1.208

52. Ministério da Saúde (BR). Documento de referência para o Programa Nacional de Segurança do Paciente. Brasília (DF): Ministério da Saúde; 2014.

53. Gomes ATL, Assis IMS, Silva MF, Costa IKF, Feijão AR, Santos VEP. Erros na administração de medicamentos: evidências e Implicações na segurança do paciente. Cogitare Enferm. 2016 Jul/set; [cited 2016 Jul 15]; 21(3):01-11. Avaliable from: http://revistas. ufpr.br/cogitare/article/view/44472/pdf
Correspondence: Elaine Cristina Novatzki Forte Universidade Federal de Santa Catarina Programa de Pós-Graduação em Enfermagem 88040-900 - Trindade, Florianópolis, SC, Brasil E-mail: elainecnforte@gmail.com
Received: April 28, 2016 Approved: February 03, 2017 